\title{
Zachorowalność i chorobowość na nowotwory układu krwiotwórczego w Polsce (2009-2015) określone na podstawie analizy danych Narodowego Funduszu Zdrowia wykorzystanych w projekcie „Mapy potrzeb zdrowotnych - baza analiz systemowych i wdrożeniowych"
}

\author{
Incidence and disease prevalence for hematologic neoplasms \\ in Poland (2009-2015) as determined on the analysis \\ of the National Health Fund data used in the project \\ 'Maps of healthcare needs - database of systemic \\ and implementation analyses'
}

\author{
Bożena Katarzyna Budziszewska1,2, Barbara Więckowska ${ }^{3,4}$, Ewa Lech-Marańda ${ }^{1,2}$, \\ Tomasz Mikołajczyk ${ }^{3}$, Janusz Dagiel ${ }^{3}$, Wiesław Wiktor Jędrzejczak ${ }^{5}$ \\ ${ }^{1}$ Klinika Hematologii, Instytut Hematologii i Transfuzjologii, Warszawa \\ ${ }^{2}$ Klinika Hematologii i Transfuzjologii, Centrum Medyczne Kształcenia Podyplomowego, Warszawa \\ ${ }^{3}$ Departament Analiz i Strategii, Ministerstwo Zdrowia, Warszawa \\ ${ }^{4}$ Katedra Ubezpieczenia Społecznego, Szkoła Główna Handlowa w Warszawie \\ ${ }^{5}$ Katedra i Klinika Hematologii, Onkologii i Chorób Wewnętrznych, Warszawski Uniwersytet Medyczny
}

\section{Streszczenie}

W Polsce brakuje danych statystycznych dotyczacych nowotworów uktadu krwiotwórczego. Zapotrzebowanie na dane epidemiologiczne dotyczqce tych nowotworów wynika zarówno z potrzeb systemowych, jak i naukowych. Ponieważ wszystkie świadczenia udzielane chorym na te nowotwory sa sprawozdawane do Narodowego Funduszu Zdrowia (NFZ), celem pracy byta próba wykorzystania danych NFZ do oceny zachorowalności i chorobowości na nowotwory mielopoetycznej części uktadu krwiotwórczego w Polsce, a także określenia catkowitego przeżycia (OS) chorych na te nowotwory. Analize wykonano $w$ ramach projektu „Mapy potrzeb zdrowotnych - baza analiz systemowych $i$ wdrożeniowych", wspótfinansowanego przez Unie Europejska ze środków Europejskiego Funduszu Spotecznego w ramach Programu Operacyjnego Wiedza Edukacja Rozwój. Wspótczynnik zapadalności rejestrowanej na ostre biataczki szpikowe (AML) wynióst w 2014 roku 4,1/100 tys., a wskaźnik chorobowości rejestrowanej - 10,9/100 tys. Mediana OS chorych zarejestrowanych $w$ systemie NFZ w latach 2009-2015 z rozpoznaniami AML wynosita 6 miesiecy, szacowane 3i 5-letnie OS osiagnęto, odpowiednio, 26,5\% i 23,4\% chorych. W 2014 roku wspótczynnik zapadalności i chorobowości na przewlekta biataczkę szpikowa (CML) wynióst odpowiednio 1,0/100 tys. i 7,2/100 tys., na nowotwory mieloproliferacyjne Filadelfia-ujemne (MPN Ph-) - 8,9/100 tys. i 55,9/100 tys., a na zespoty mielodysplastyczne (MDS) - 3,8/100 tys. i 11,5/100 tys. Dla chorych zarejestrowanych w systemie NFZ kodem CML prawdopodobieństwo 3- i 5-letniego OS wynosito

Adres do korespondencji: Ewa Lech-Marańda, Klinika Hematologii, Instytut Hematologii i Transfuzjologii, ul. Indiry Gandhi 14, 02-776 Warszawa, tel. 223496 302, faks 223496 335, e-mail: emaranda@ihit.waw.pl 
odpowiednio 76,2\% i 68,1\%. Dla chorych rejestrowanych kodami MPN Ph(-) prawdopodobieństwo 3- $i$ 5-letniego OS oszacowano odpowiednio na 86,6\% oraz 78,6\%. Z kolei mediana OS u chorych raportowanych kodem MDS wynosita 30 miesiecy, prawdopodobieństwo 3-letniego OS osiagnęto 45,8\%, a 5-letniego OS - 36,1\% chorych. Dane sprawozdawane do NFZ w celu uzyskania refundacji świadczeń wydaja sie najbardziej rzetelnymi danymi obejmujacymi tak duza populacje chorych. Jednak nawet sprawozdawczość do NFZ może być obarczona btędem wynikajacym z niedostatecznej jakości systemu kodowania chorób nowotworowych oraz niedostosowaniem X Rewizji ICD-10 (International Classification of Diseases) do obowiazujacych klasyfikacji Światowej Organizacji Zdrowia. Tym niemniej uzyskane wyniki sq zbliżone do danych z rejestrów europejskich i amerykańskich w odniesieniu do AML $i M D S$, a w zakresie $M P N$ (z wyjatkiem $C M L)$ wymagaja dalszej weryfikacji.

Słowa kluczowe: zapadalność rejestrowana, chorobowość rejestrowana, prawdopodobieństwo przeżycia całkowitego, ostre białaczki szpikowe, nowotwory mieloproliferacyjne, zespół mielodysplastyczny

Hematologia 2017; 8, 2: 89-104

\section{Abstract}

In Poland, there is a shortage of statistical data regarding neoplasia of hematopoietic system. There is an unmet demand for epidemiological data concerning such cancers stemming from both scientific and health care management reasons. As all medical services for patients with these disorders are reported to the National Health Fund (NFZ) the aim of this study was to use NFZ data for determining incidence and prevalence of neoplasia of myelopoietic part of hematopoietic system in Poland, as well as defining the overall survival (OS) in affected patients. This work was performed under the project 'Map of healthcare needs - database of systemic and implementation analyses' co-funded by the European Union Social Fund from the Operational Programme for the Development of Knowledge and Education. The incidence rate in 2014 for acute myeloid leukaemia (AML) was 4.1/100,000 whilst the registered disease prevalence rate was 10.9/100,000. The median OS during 2009-2015 for AML - reported patients was 6 months and the 3-and 5-year OS was estimated as respectively being $26.5 \%$ and $23.4 \%$. For chronic myelogenous leukemia (CML) the incidence and disease prevalence rates were 1.0/100,000 and 7.2/100,000 respectively, and those for Philadelphia-negative myeloproliferative neoplasms (MPN Ph-) were 8.9/100,000 and 55.9/100,000 respectively, whilst those for myelodysplastic syndromes (MDS) were 3.8/100,000 and 11.5/100,000 respectively. In patients reported as having CML, the 3- and 5-year OS was $76.2 \%$ and $68.1 \%$ respectively. In patients reported as having $M P N P h(-)$, the 3-and 5-year OS was $86.6 \%$ and $78.6 \%$ respectively. The median OS for patients reported as having MDS was 30 months and the probability of patients achieving 3- and 5-year OS was $45.8 \%$ and $36.1 \%$ respectively. Data reported to the NFZ for reimbursement of medical services provided seem to be the most reliable concerning such large patient population. Yet, there are still prone to errors arising from the mis-coding of cancers and to limited compatibility of the ICD-10 th Revision (International Classification of Diseases) to current World Health Organization classification, Nevertheless, our data are similar to the European and USA registers regarding AML and MDS. However, in the case of $M P N s$ (CML excluding) they require further verification.

Key words: registered incidence, registered disease prevalence, probability of overall survival, acute myeloid leukemia, myeloproliferative neoplasms, myelodysplastic syndrome

Hematologia 2017; 8, 2: 89-104 


\section{Wprowadzenie}

Zapotrzebowanie na dane epidemiologiczne dotyczące nowotworów układu krwiotwórczego wynika zarówno $z$ powodów systemowych (ocena potrzeb zdrowotnych społeczeństwa niezbędna do właściwego zaplanowania odpowiedniego poziomu kontraktowania oraz potrzeb kadrowych i instytucjonalnych koniecznych do ich zabezpieczenia), jak i potrzeb naukowych (planowanie badań, szacowanie skali problemu diagnostycznego i leczniczego, który badacz pragnie rozwiązać). Zgłoszenia przypadków zachorowań na nowotwory złośliwe w Polsce są gromadzone w Krajowym Rejestrze Nowotworów (KRN). Wprawdzie KRN obejmuje również nowotwory krwi, ale nie umożliwia analizy chorobowości, a dane dotyczące zachorowalności też wydają się, $z$ różnych przyczyn, niedoszacowane. $W$ odniesieniu do guzów litych w KRN stwierdzono średnie 26-procentowe niedoszacowanie liczby nowotworów w Polsce - w zależności od rodzaju nowotworu waha się ona w przedziale od 14\% (nowotwór piersi) do 50\% (nowotwór ślinianek) [1]. Obecnie w Polsce obowiązuje X Rewizja Międzynarodowej Statystycznej Klasyfikacji Chorób i Problemów Zdrowotnych (ICD-10, International Statistical Classification of Diseases and Health-Related Problems), a wszystkie podmioty prowadzące badania statystyczne w ramach programu badań statystyki publicznej są zobowiązane do jej stosowania.

W bazie KRN nowotwory krwi są pogrupowane w następujący sposób: chłoniak Hodgkina (ICD-10 C81), nowotwory tkanki limfatycznej i krwiotwórczej (ICD-10 C81-C96), chłoniaki nie-Hodgkina (ICD-10 C82-C85), szpiczak plazmocytowy i nowotwory z komórek plazmatycznych (ICD-10 C90), białaczki (ICD-10 C91-95), białaczka limfatyczna (ICD-10 C91), białaczka szpikowa (ICD-10 C92). Takie pogrupowanie utrudnia uzyskanie danych epidemiologicznych dotyczących nowotworów krwi zgodnie $z$ obowiązującą klasyfikacją Światowej Organizacji Zdrowia (WHO, World Health Organization), w której wyodrębniono dwie podstawowe grupy nowotworów krwi, tj. nowotwory układu krwiotwórczego i nowotwory układu chłonnego, a następnie w obrębie wyżej wymienionych grup sklasyfikowano poszczególne rozpoznania nowotworów. Rozszerzenia kodów ICD-10 stosowanych w rejestrze KRN ograniczają się do dwóch pierwszych cyfr, co między innymi uniemożliwia odróżnienie ostrej białaczki limfoblastycznej (C91.0) od przewlekłej białaczki limfocytowej (C91.1) oraz ostrych białaczek szpikowych (AML, acute myeloid leukemias) od przewlekłej białaczki szpikowej (CML, chronic myelogenous leukemia) (C92.1). Wreszcie, w KRN nie są uwzględnione wszystkie nowotwory krwi - pomija się te, które są określone kodami $z$ kategorii D. Obejmuje to zespoły mielodysplastyczne (MDS, myelodysplastic syndromes) (D46) oraz niektóre nowotwory mieloproliferacyjne (MPN, myeloproliferative neoplasms), tj. czerwienicę prawdziwą ( $\mathrm{PV}$, polycythemia vera) (D45), pierwotną mielofibrozę (PMF, primary myelofibrosis) (D47.1) i nadpłytkowość samoistną (ET, essential thrombocythemia) (D75.2).

Jednocześnie wszystkie podmioty lecznicze finansowane ze środków publicznych, sprawozdając wykonanie świadczeń do Narodowego Fundusz Zdrowia (NFZ), wskazują również na rozpoznania według klasyfikacji ICD-10, tyle $\dot{z}$ e w układzie 5-znakowym, co umożliwia bardziej precyzyjne określenie rodzaju nowotworu, w tym rozróżnienie białaczek ostrych od przewlekłych. $Z$ tego względu to sprawozdawanie jest bardziej dokładne niż zgłaszalność do KRN. Co więcej, ze względu na raportowanie do poziomu PESEL, analiza ścieżki leczenia pacjenta może dodatkowo umożliwić ocenę chorobowości.

Celem niniejszej pracy była próba analizy danych NFZ w celu oceny zachorowalności i chorobowości na najważniejsze nowotwory układu krwiotwórczego w Polsce, a także określenia przeżycia całkowitego (OS, overall survival) osób z tymi nowotworami niezależnie od przyczyny zgonu.

\section{Materiał i metody}

Analiza została wykonana w ramach projektu pt. „Mapy potrzeb zdrowotnych — baza analiz systemowych i wdrożeniowych" współfinansowanego przez Unię Europejską ze środków Europejskiego Funduszu Społecznego w ramach Programu Operacyjnego Wiedza Edukacja Rozwój. W ramach realizacji projektu w 31 grudnia 2016 roku na stronie Ministerstwa Zdrowia opublikowano „Mapy potrzeb zdrowotnych - bazę analiz systemowych i wdrożeniowych" [2]. Projekt realizuje Departament Analiz i Strategii Ministerstwa Zdrowia, a jego celem jest poprawa jakości zarządzania $\mathrm{w}$ systemie ochrony zdrowia poprzez wsparcie decyzji zarządczych opartych na danych. Regularne przygotowywanie i publikowanie analiz ma doprowadzić do dyskusji merytorycznej na temat systemu ochrony zdrowia oraz merytorycznego wyjaśniania decyzji zarządczych zarówno na poziomie krajowym (poziom makro), poziomie regionalnym (poziom mezo), jak i poziomie poszczególnych świadczeniodawców (poziom mikro). 
W „Mapach potrzeb zdrowotnych — bazie analiz systemowych i wdrożeniowych" nowotwory krwi pogrupowano na podstawie klasyfikacji WHO, posługując się kodami klasyfikacji ICD-10 stosowanymi w sprawozdawczości dla NFZ. $\mathrm{W}$ analizach wykorzystano, poddane pseudoanonimizacji, dane sprawozdane do NFZ komunikatem SWIAD za okres od 1 stycznia 2014 do 31 grudnia 2014 roku oraz dane dotyczące zgonów odnotowanych w Centralnym Wykazie Ubezpieczonych. Analizy przeprowadzono w odniesieniu do chorych sprawozdawanych do NFZ z rozpoznaniami ostrych nowotworów układu krwiotwórczego, czyli AML, a więc kodowanych jako C92, C93, C94, C95 z wyłączeniem kodów C92.1, C93.1, C94.1, C95.1, oraz w odniesieniu do chorych sprawozdawanych $z$ rozpoznaniami przewlekłych nowotworów układu krwiotwórczego, takich jak CML (C92.1) i MPN Filadelfia (Ph, Philadelphia)-ujemne (Ph-) (D45, D47.1, C94.1, D75.2), oraz chorych na MDS (D46).

Biorąc pod uwagę fakt, że nowotwory krwi, $z$ epidemiologicznego punktu widzenia, należą do chorób nieprzemijających, tj. chorób przewlekłych, obliczono zapadalność rejestrowaną oraz chorobowość rejestrowaną dla poszczególnych grup nowotworów. Dookreślenie „rejestrowana” zostało wprowadzone w celu zaznaczenia, że nie jest to zapadalność lub chorobowość określana na podstawie badań epidemiologicznych, lecz wynikająca ze zdarzeń zarejestrowanych przez płatnika publicznego.

Współczynnik zapadalności rejestrowanej zdefiniowano jako liczbę nowych pacjentów $z$ danym rozpoznaniem sprawozdanych $\mathrm{w}$ ramach systemu ochrony zdrowia finansowanego ze środków publicznych w przeliczeniu na 100 tys. mieszkańców w ciągu roku. W przypadku chorób przewlekłych zapadalność obliczono dla roku 2014, na podstawie danych NFZ z lat 2009-2015 (możliwość analizy historii pacjenta co najmniej 5 lat wstecz i rok w przód). Pacjenta sprawozdawanego do NFZ $\mathrm{w}$ tym okresie uznawano za nowego pacjenta (pacjenta pierwszorazowego), jeżeli wystąpił $z$ danym rozpoznaniem po raz pierwszy w roku 2014. Liczba nowych przypadków pacjentów w publicznym systemie opieki zdrowotnej (zapadalność rejestrowana) powinna uwzględniać każde pierwsze pojawienie się pacjenta w systemie. Jednak ze względu na fakt, że analizę przeprowadzano na danych NFZ, gdzie jest możliwe sprawozdanie rozpoznania, które później nie będzie potwierdzone po skierowaniu do ośrodka specjalistycznego, przyjęto regułę, że tylko pacjenci, którzy w systemie publicznej opieki zdrowotnej pojawili się co najmniej 2-krotnie, mogą być traktowani jako chorzy $z$ danym rozpoznaniem, co tym samym oznacza zachorowanie na daną chorobę. W przypadku zapadalności na AML, zważywszy na jej przebieg kliniczny, oprócz przyjętego kryterium co najmniej 2-krotnego pojawienia się systemie publicznej opieki zdrowotnej, by można było uznać rozpoznanie tego nowotworu, zastosowano dodatkowe kryterium identyfikacji nowego zachorowania, tj. jednokrotną rejestrację w systemie $z$ następowym zgonem. Rozważono trzy drogi „wejścia” pacjenta do systemu — szpital, ambulatoryjną opiekę specjalistyczną (AOS) oraz szpitalny oddział ratunkowy (SOR). Współczynniki zapadalności rejestrowanej na 2014 rok analizowano w przekroju uwzględniającym grupę wiekową i płeć.

Chorobowość oceniano, rejestrując wszystkich chorych sprawozdanych w danym roku - sumowano liczbę chorych po raz pierwszy zgłoszonych do systemu w danym roku oraz chorych, którzy byli zgłoszeni w grupie nowych rozpoznań w poprzednich latach i nadal żyją w roku, w odniesieniu do którego jest prowadzona analiza, niezależnie od tego, czy w tym roku udzielono im świadczeń z powodu nowotworu krwi. Chorobowość rejestrowaną oszacowano na 31 grudnia 2014 roku, co oznacza, że za chorych w tym dniu uznano wszystkich pacjentów zaklasyfikowanych w grupie nowych przypadków zachorowania w publicznym systemie opieki zdrowotnej od 2009 roku i którzy nie zmarli do 31 grudnia 2014 roku.

Należy dodać, ̇̇e w analizach na poziomie województw brano pod uwagę deklarowane płatnikowi publicznemu miejsce zamieszkania pacjenta, a nie miejsce udzielania świadczenia. Ponadto w przeprowadzonych badaniach oszacowano prawdopodobieństwo całkowitego przeżycia (OS, overall survival). Do tego celu wykorzystano metodę Kaplana-Meiera. Czas przeżycia pacjenta liczono od daty rozpoznania do daty zgonu, niezależnie od jego przyczyny.

Analizy i wizualizacje wykonano $\mathrm{z}$ wykorzystaniem oprogramowania $\mathrm{R} w$ wersji 3.3.1, $\mathrm{z}$ użyciem IDE RStudio w wersji 1.0.136 [3-8].

\section{Wyniki}

\section{Ostre białaczki szpikowe}

Zapadalność rejestrowana na AML u dorosłych w roku 2014 wyniosła 1,6 tys. przypadków w Polsce, a współczynnik zapadalności rejestrowanej na 
100 tys. ludności - 4,1. Liczbę chorych na AML w Polsce oszacowano na 4,2 tys., a współczynnik chorobowości rejestrowanej w przeliczeniu na 100 tys. wyniósł 10,9. Wartości współczynników zapadalności i chorobowości rejestrowanej dla poszczególnych województw przedstawiono w tabeli $1 . \mathrm{Na}$ rycinie 1 przedstawiono zapadalność na AML, przy czym wielkość okręgu odzwierciedla bezwzględną liczbę nowych przypadków w danym województwie (maksymalna w województwie mazowieckim 220 , minimalna w województwie opolskim - 38), z uwzględnieniem trzech dróg „wejścia” pacjenta do systemu, tj. szpital, AOS i SOR. Intensywność koloru województwa przedstawia poziom zapadalności na 100 tys. ludności (wartość najniższa 3,0województwo świętokrzyskie, wartość najwyższa 4,9 - województwo lubuskie).

W grupie chorych $z$ rozpoznaniami AML w 2014 roku udział mężczyzn (53\%) i kobiet (47\%) był zbliżony. Strukturę zapadalności rejestrowanej na AML według płci dla poszczególnych województw przedstawiono na rycinie 2 . Wyjątek stanowi województwo opolskie, gdzie udział kobiet jest o 16 punktów procentowych niższy od średniej.

Mediana wieku chorych sprawozdawanych z użyciem kodów AML wynosiła 65 lat (zakres 18-101 lat) i była podobna u kobiet (mediana 65 lat, zakres 18-98 lat) i u mężczyzn (mediana
Tabela 1. Wskaźniki zapadalności i chorobowości rejestrowanej na ostre białaczki szpikowe w poszczególnych województwach

Table 1. Registered incidence and disease prevalence rates for acute myeloid leukemia according to defined regions of Poland

\begin{tabular}{|l|c|c|}
\hline Kraj/województwo & $\begin{array}{c}\text { Zapadalność* } \\
\text { /100 tys. }\end{array}$ & $\begin{array}{c}\text { Chorobowoś́́ } \\
\text { /100 } \text { tys. }\end{array}$ \\
\hline POLSKA & 4,1 & 10,9 \\
\hline dolnośląskie & 4,6 & 10,0 \\
\hline kujawsko-pomorskie & 4,3 & 9,7 \\
\hline lubelskie & 3,9 & 9,9 \\
\hline lubuskie & 4,9 & 15,0 \\
\hline łódzkie & 4,1 & 13,4 \\
\hline małopolskie & 4,0 & 11,4 \\
\hline mazowieckie & 4,1 & 10,5 \\
\hline opolskie & 3,9 & 8,1 \\
\hline podkarpackie & 3,6 & 8,8 \\
\hline podlaskie & 3,6 & 7,7 \\
\hline pomorskie & 4,3 & 12,9 \\
\hline śląskie & 4,0 & 11,3 \\
\hline świętokrzyskie & 3,0 & 12,3 \\
\hline warmińsko-mazurskie & 3,9 & 11,4 \\
\hline wielkopolskie & 4,6 & 11,4 \\
\hline zachodniopomorskie & 3,5 & 9,9 \\
\hline
\end{tabular}

*Różnice w zakresie zapadalności i chorobowości między wartościami prezentowanymi w tabeli 1 a wartościami przedstawionymi w mapach potrzeb zdrowotnych wynikają z zastosowania dodatkowego kryterium identyfikacji nowego zachorowania na ostre białaczki szpikowe, jakim było jednokrotne zarejestrowanie $\mathrm{w}$ systemie $\mathrm{z}$ następowym zgonem

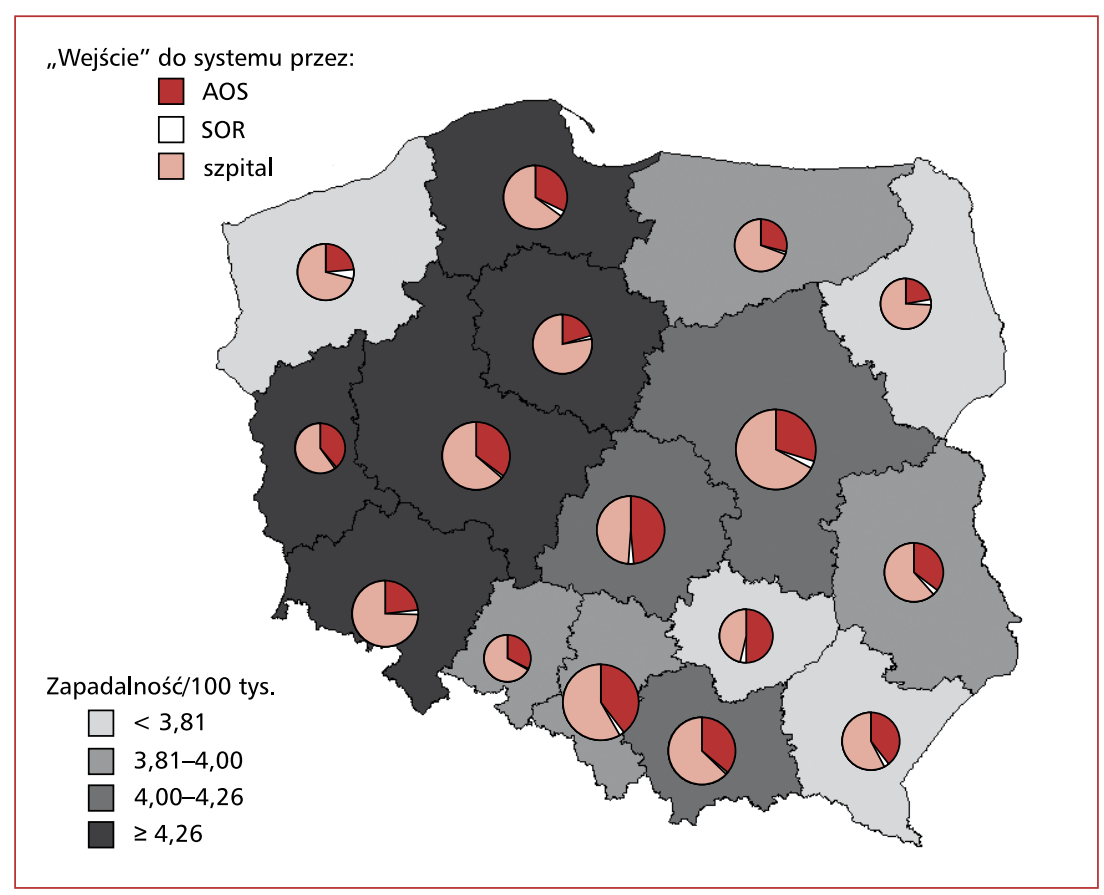

Rycina 1. Zapadalność rejestrowana na ostre białaczki szpikowe w poszczególnych województwach; AOS — ambulatoryjna opieka specjalistyczna; SOR — szpitalny oddział ratunkowy

Figure 1. The registered incidence rate for acute myeloid leukemia according to defined regions of Poland; AOS outpatient specialist care; SOR — hospital emergency ward 


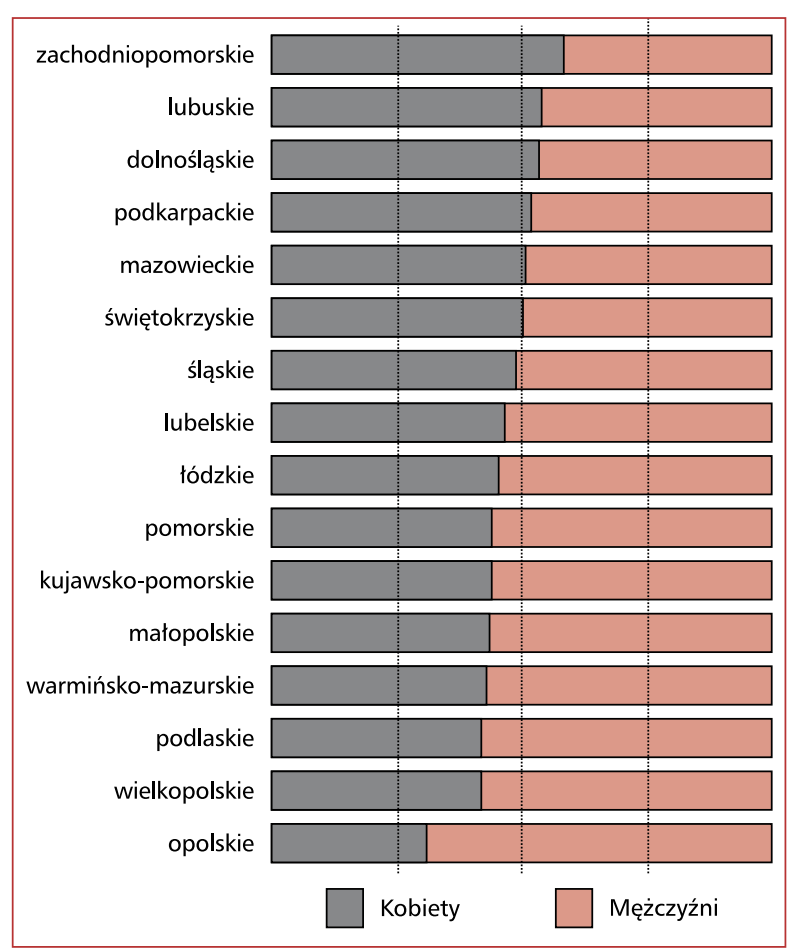

Rycina 2. Struktura zapadalności rejestrowanej na ostre białaczki szpikowe według płci w poszczególnych województwach

Figure 2. A pattern of registered incidence for acute myeloid leukemia according to the gender and regions of Poland

64 lat, zakres 18-101 lat). Na rycinie 3 przedstawiono strukturę zapadalności rejestrowanej według grupy wiekowej, a na rycinie 4 przeanalizowano zapadalność rejestrowaną według

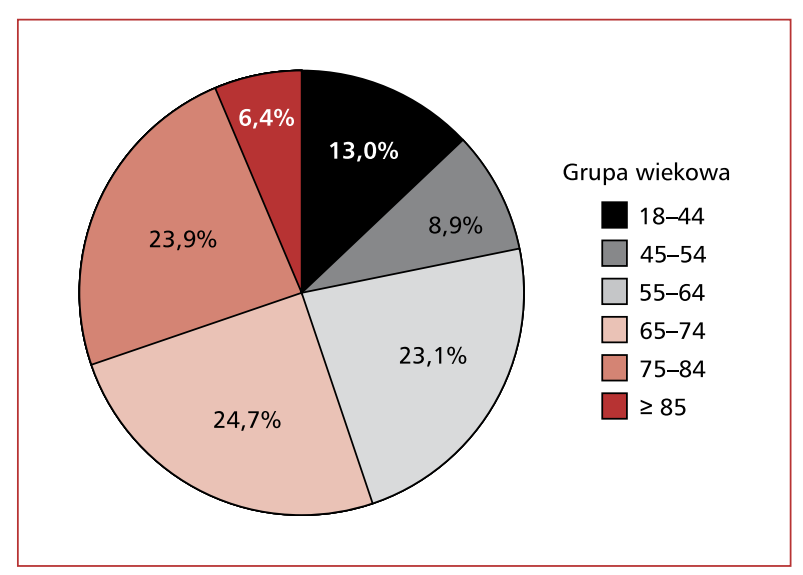

Rycina 3. Struktura zapadalności rejestrowanej na ostre białaczki szpikowe według grupy wiekowej

Figure 3. A pattern of registered incidence for acute myeloid leukemia according to the age group

grupy wiekowej w odniesieniu do poszczególnych województw.

Na podstawie danych dotyczących dat zgonów oszacowano prawdopodobieństwo OS u wszystkich chorych zarejestrowanych w systemie NFZ w latach 2009-2014 z rozpoznaniami AML, tj. C92, C93, C94, C95, z wylączeniem C92.1, C93.1, C94.1, C95.1 (ryc. 5). Mediana OS wynosiła 6 miesięcy. Szacowane 3-letnie OS osiągnęło 26,5\% chorych, a 5-letnie OS - 23,4\% chorych. Obliczono również prawdopodobieństwo OS u chorych sprawozdanych z użyciem wyżej wymienionych kodów ICD-10 w zależności od grupy wiekowej z przedstawieniem ich 3- i 5-letnich wartości (ryc. 6, tab. 2).

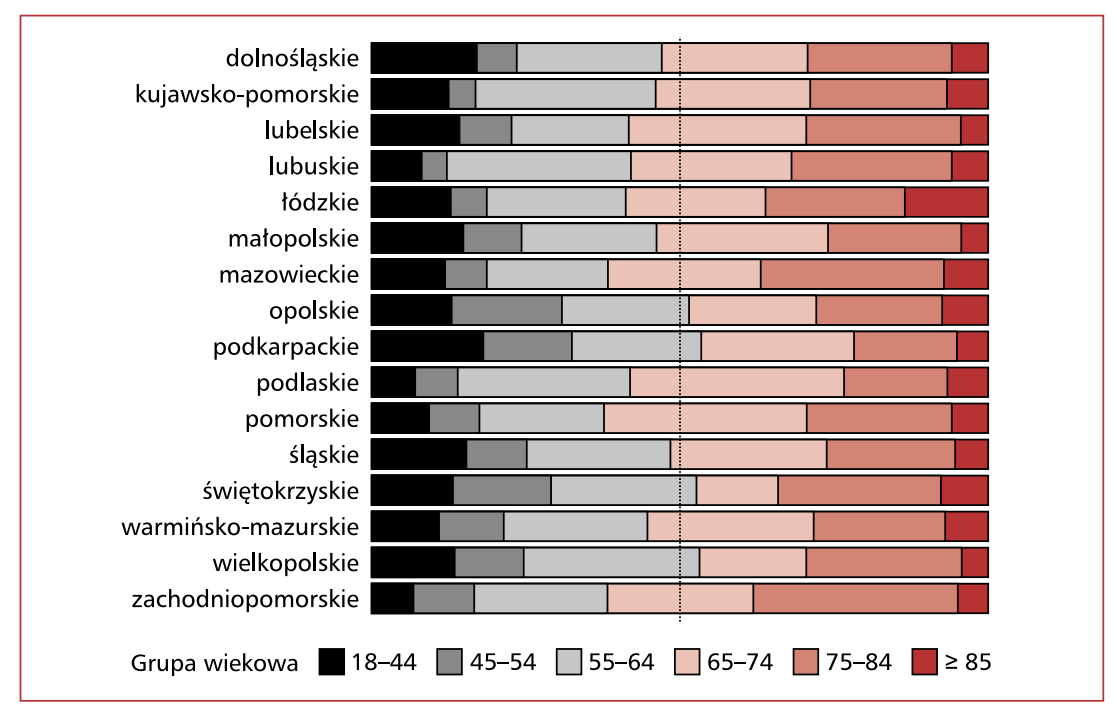

Rycina 4. Struktura zapadalności rejestrowanej na ostre białaczki szpikowe według grupy wiekowej w poszczególnych województwach

Figure 4. A pattern of registered incidence for acute myeloid leukemia according to the age group and regions of Poland 


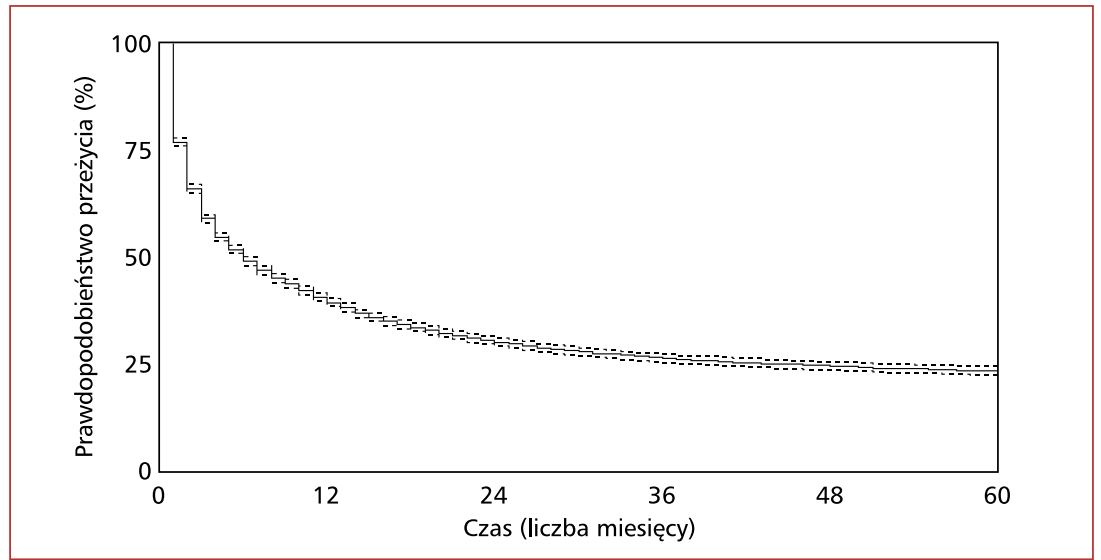

Rycina 5. Prawdopodobieństwo całkowitego przeżycia chorych sprawozdawanych jako pacjenci z rozpoznaniami ostrych białaczek szpikowych

Figure 5. Probability of overall survival in patients registered as having acute myeloid leukemias

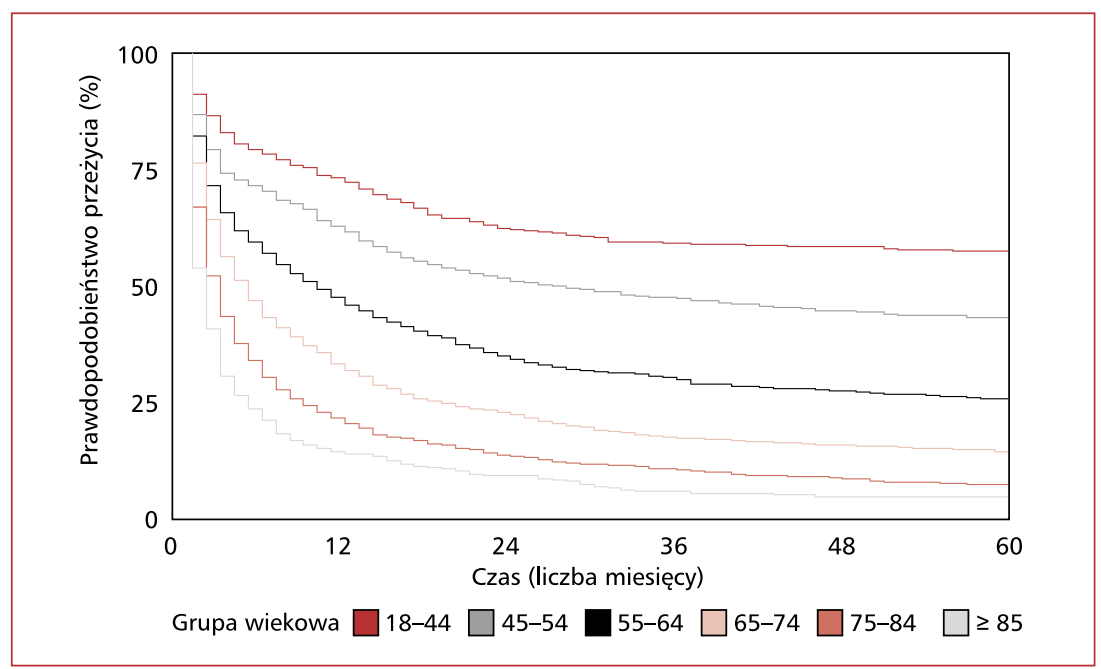

Rycina 6. Prawdopodobieństwo całkowitego przeżycia chorych sprawozdawanych jako pacjenci z rozpoznaniami ostrych białaczek szpikowych w zależności od grupy wiekowej

Figure 6. Probability of overall survival in patients registered as having acute myeloid leukemias according to the age group

Tabela 2. Szacowane 3- i 5-letnie przeżycia całkowite (OS) chorych sprawozdawanych jako pacjenci z rozpoznaniami ostrych białaczek szpikowych w zależności od grupy wiekowej

Table 2. Estimated 3- and 5 year overall survival (OS) in patients registered as having acute myeloid leukemias according to the age group

\begin{tabular}{|l|c|c|c|}
\hline Grupa wiekowa (lata) & Mediana (miesiące) & 3-lenie OS (zakres) & 5-lenie OS (zakres) \\
\hline $18-44$ & $>60$ & $59 \%(56-62 \%)$ & $57 \%(55-61 \%)$ \\
\hline $45-54$ & 27 & $47 \%(44-51 \%)$ & $43 \%(40-47 \%)$ \\
\hline $55-64$ & 10 & $30 \%(28-32 \%)$ & $25 \%(23-28 \%)$ \\
\hline $65-74$ & 5 & $17 \%(15-19 \%)$ & $14 \%(12-16 \%)$ \\
\hline $75-84$ & 3 & $10 \%(9-12 \%)$ & $7 \%(6-9 \%)$ \\
\hline$\geq 85$ & 2 & $6 \%(4-8 \%)$ & $4 \%(3-7 \%)$ \\
\hline
\end{tabular}


Tabela 3. Wskaźniki zapadalności i chorobowości rejestrowanej na przewlekłe nowotwory układu krwiotwórczego w poszczególnych województwach

Table 3. Registered incidence and disease prevalence rates for chronic hematologic neoplasms according to defined regions of Poland

\begin{tabular}{|l|c|c|}
\hline Kraj/województwo & $\begin{array}{c}\text { Zapadalność/ } \\
/ 100 \text { tys. }\end{array}$ & $\begin{array}{c}\text { Chorobowość/ } \\
/ 100 \text { tys. }\end{array}$ \\
\hline POLSKA & 19,2 & 111,6 \\
\hline dolnośląskie & 23,1 & 121,8 \\
\hline kujawsko-pomorskie & 18,3 & 103,9 \\
\hline lubelskie & 15,8 & 107,1 \\
\hline lubuskie & 17,4 & 77,4 \\
\hline tódzkie & 21,4 & 118,0 \\
\hline małopolskie & 12,5 & 84,2 \\
\hline mazowieckie & 25,7 & 149,5 \\
\hline opolskie & 17,1 & 104,2 \\
\hline podkarpackie & 19,0 & 110,0 \\
\hline podlaskie & 21,7 & 126,3 \\
\hline pomorskie & 18,4 & 109,8 \\
\hline śląskie & 21,7 & 127,2 \\
\hline świętokrzyskie & 18,2 & 108,2 \\
\hline warmińsko-mazurskie & 15,0 & 72,7 \\
\hline wielkopolskie & 14,3 & 87,8 \\
\hline zachodniopomorskie & 16,3 & 95,9 \\
\hline
\end{tabular}

\section{Przewlekłe nowotwory} układu krwiotwórczego

Zapadalność rejestrowana na przewlekłe nowotwory układu krwiotwórczego u dorosłych w roku 2014 wyniosła 7,4 tys. przypadków w Polsce, zaś współczynnik zapadalności rejestrowanej na 100 tys. ludności - 19,2. Liczbę chorych na przewlekłe nowotwory układu krwiotwórczego w Polsce oszacowano na 42,9 tys., zaś współczynnik chorobowości rejestrowanej w przeliczeniu na 100 tys. mieszkańców wyniósł 111,6. Wartości wskaźników zapadalności i chorobowości rejestrowanej w odniesieniu do poszczególnych województw przedstawiono w tabeli 3. Na rycinie 7 ukazano zapadalność na przewlekłe nowotwory układu krwiotwórczego, przy czym wielkość okręgu odzwierciedla bezwzględną liczbę nowych przypadków w danym województwie (maksymalna w województwie mazowieckim - 1372, minimalna w województwie opolskim - 171), $z$ uwzględnieniem trzech dróg ,wejścia” pacjenta do systemu, tj. szpital, AOS i SOR. Intensywność koloru województwa przedstawia poziom zapadalności na 100 tys. ludności (wartość najniższa 12,5 — województwo małopolskie, wartość najwyższa 25,7 - województwo mazowieckie).

W grupie chorych sprawozdanych $z$ użyciem kodów przewlekłych nowotworów układu krwio-

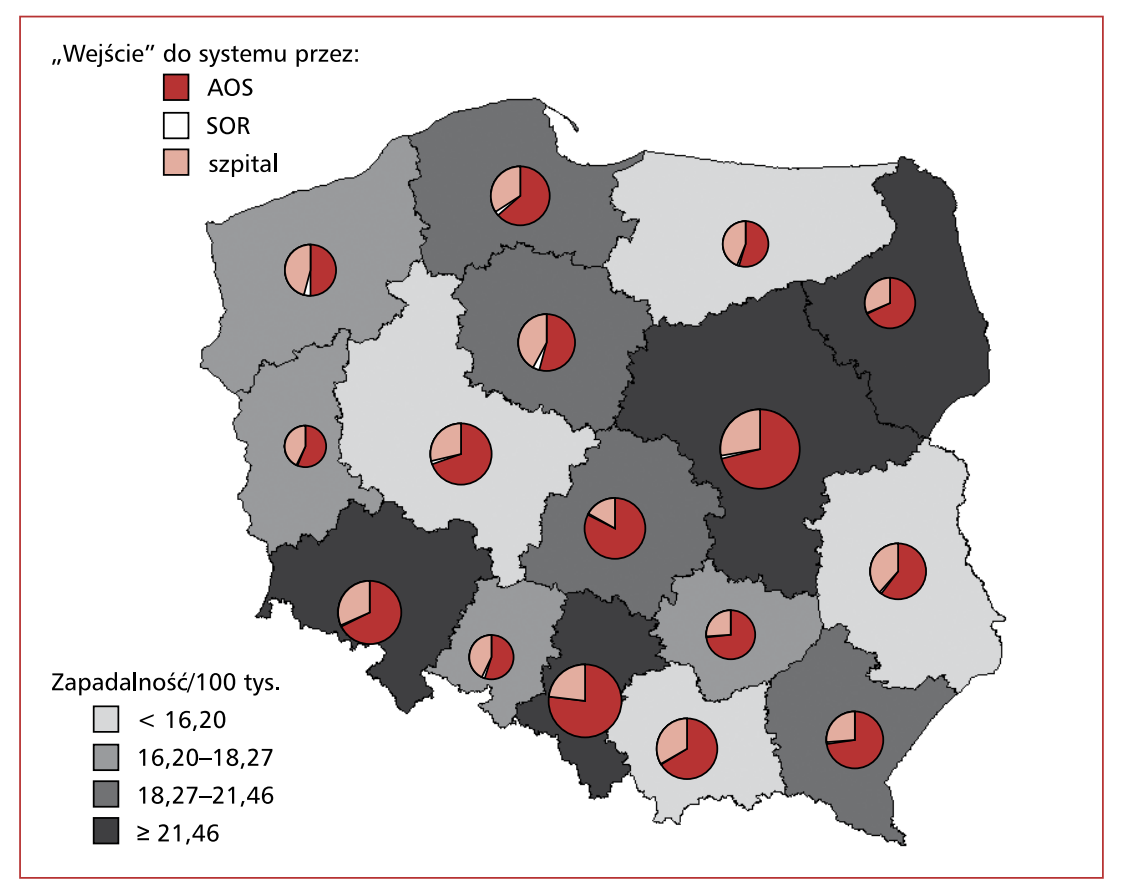

Rycina 7. Zapadalność rejestrowana na przewlekłe nowotwory układu krwiotwórczego w poszczególnych województwach

Figure 7. The registered incidence rate for chronic myeloproliferative neoplasms according to defined regions of Poland 


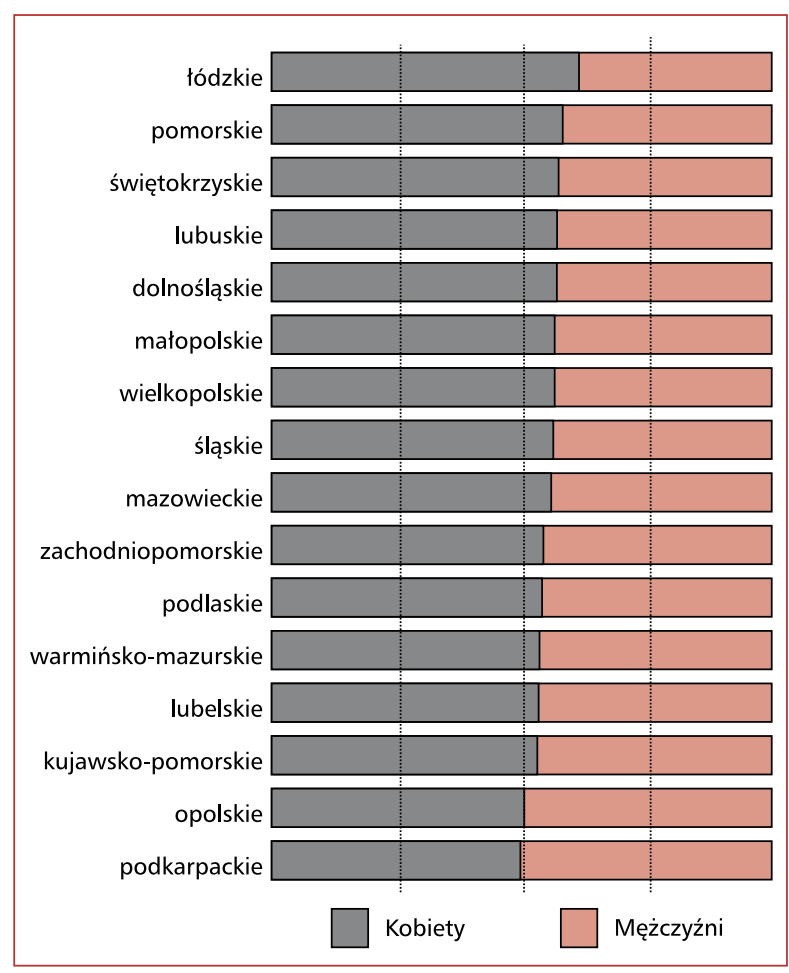

Rycina 8. Struktura zapadalności rejestrowanej na przewlekłe nowotwory układu krwiotwórczego według płci w poszczególnych województwach

Figure 8. A pattern of registered incidence for chronic myeloproliferative neoplasms according to the gender and regions of Poland

twórczego w 2014 roku udział mężczyzn wynosił $45 \%$, a kobiet - 55\%. Strukturę zapadalności rejestrowanej na przewlekłe nowotwory układu krwiotwórczego według płci w poszczególnych województwach przedstawiono na rycinie 8 .

Mediana wieku chorych na przewlekłe nowotwory układu krwiotwórczego wynosiła 65 lat (zakres 18-101 lat) i była identyczna u kobiet i u mężczyzn (mediana 65 lat, zakres 18-101 lat). Na rycinie 9 zaprezentowano strukturę zapadalności rejestrowanej według grupy wiekowej, a na rycinie 10 - zapadalność rejestrowaną według grupy wiekowej w poszczególnych województwach.

$\mathrm{W}$ grupie chorych zarejestrowanych w systemie NFZ kodami przewlekłych nowotworów układu krwiotwórczego przeprowadzono szczegółową analizę $\mathrm{w}$ odniesieniu do takich rozpoznań, jak MPN, w tym CML (C92.1) i MPN Ph(-) (D45, D47.1, C94.1, D75.2), oraz MDS (D46). Wskaźniki zapadalności i chorobowości dotyczące tych nowotworów zestawiono w tabeli 4.

Na podstawie danych dotyczących dat zgonów oszacowano prawdopodobieństwo OS u wszystkich chorych zarejestrowanych w systemie NFZ w latach 2009-2015 z użyciem kodów CML (ryc. 11A),

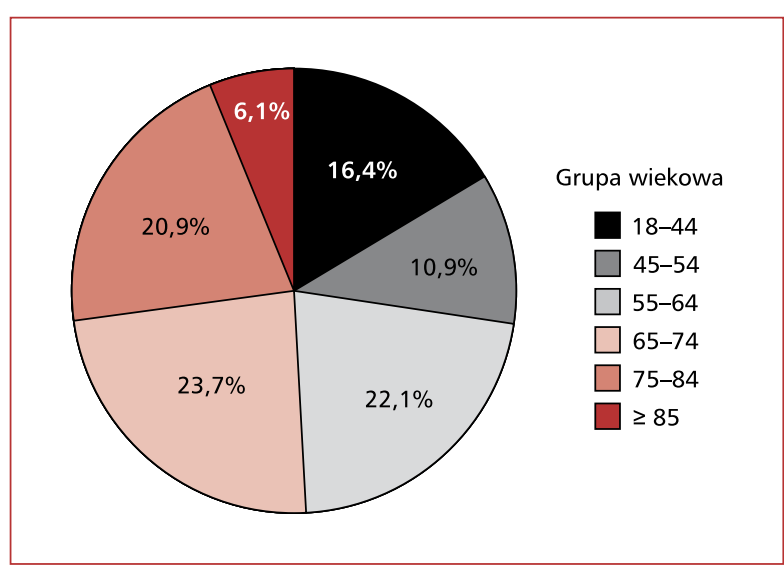

Rycina 9. Struktura zapadalności rejestrowanej na przewlekłe nowotwory układu krwiotwórczego według grupy wiekowej

Figure 9. A pattern of registered incidence for chronic myeloproliferative neoplasms according to the age group

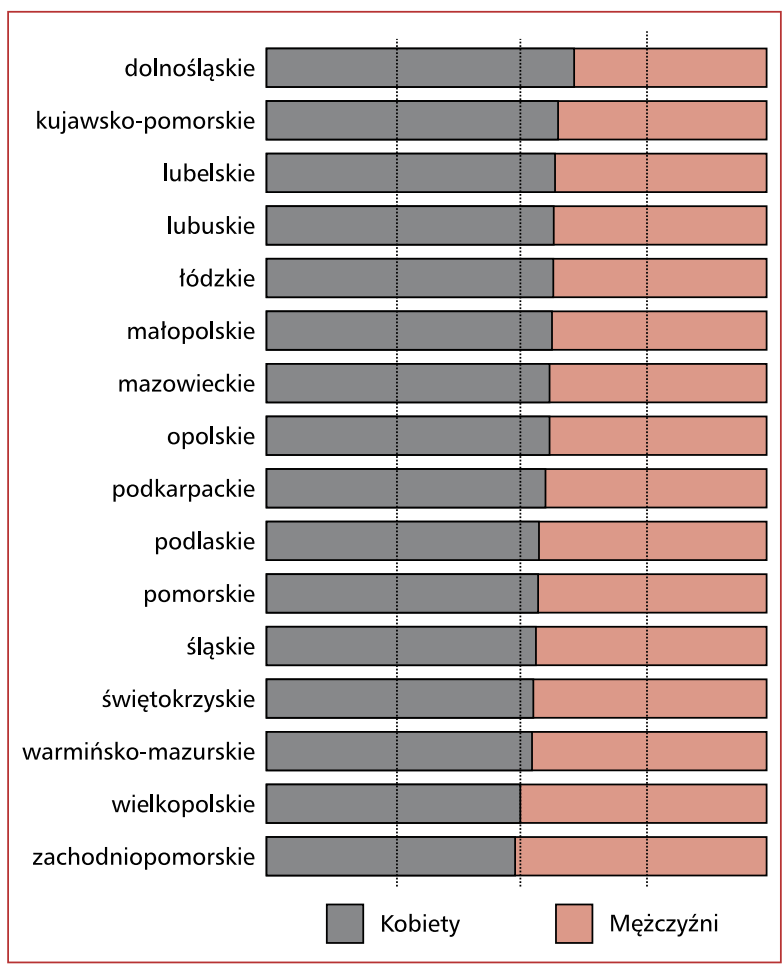

Rycina 10. Struktura zapadalności rejestrowanej na przewlekłe nowotwory układu krwiotwórczego według grupy wiekowej w poszczególnych województwach

Figure 10. A pattern of registered incidence for chronic myeloproliferative neoplasms according to the age group and regions of Poland

MPN Ph(-) (ryc. 12A) oraz MDS (ryc. 13A). U chorych sprawozdawanych do NFZ z użyciem kodu CML prawdopodobieństwo 3- i 5-letniego OS wynosiło, odpowiednio, $76,2 \%$ i $68,1 \%$. U chorych 
Hematologia 2017, tom 8, nr 2

Tabela 4. Wskaźniki zapadalności i chorobowości rejestrowanej na nowotwory mieloproliferacyjne i zespoły mielodysplastyczne Table 4. Registered incidence and disease prevalence rates for myeloproliferative neoplasms and myelodysplatic syndromes

\begin{tabular}{|l|c|c|}
\hline Podgrupa & Zapadalność/100 tys. & Chorobowość/100 tys. \\
\hline Przewlekła białaczka szpikowa & 1,0 & 7,2 \\
\hline Przewlekłe nowotwory mieloproliferacyjne Ph & 8,9 & 55,9 \\
\hline Zespoły mielodysplastyczne & $3,8^{*}$ & 11,5 \\
\hline
\end{tabular}

*Odrzucono przypadki pacjentów, którzy z rozpoznaniem D46 pojawiali się w ambulatoryjnej opiece specjalistycznej, a nigdy nie pojawili się w szpitalu z rozpoznaniem zespołu mielodysplastycznego; Ph (Philadelphia) - Filadelfia

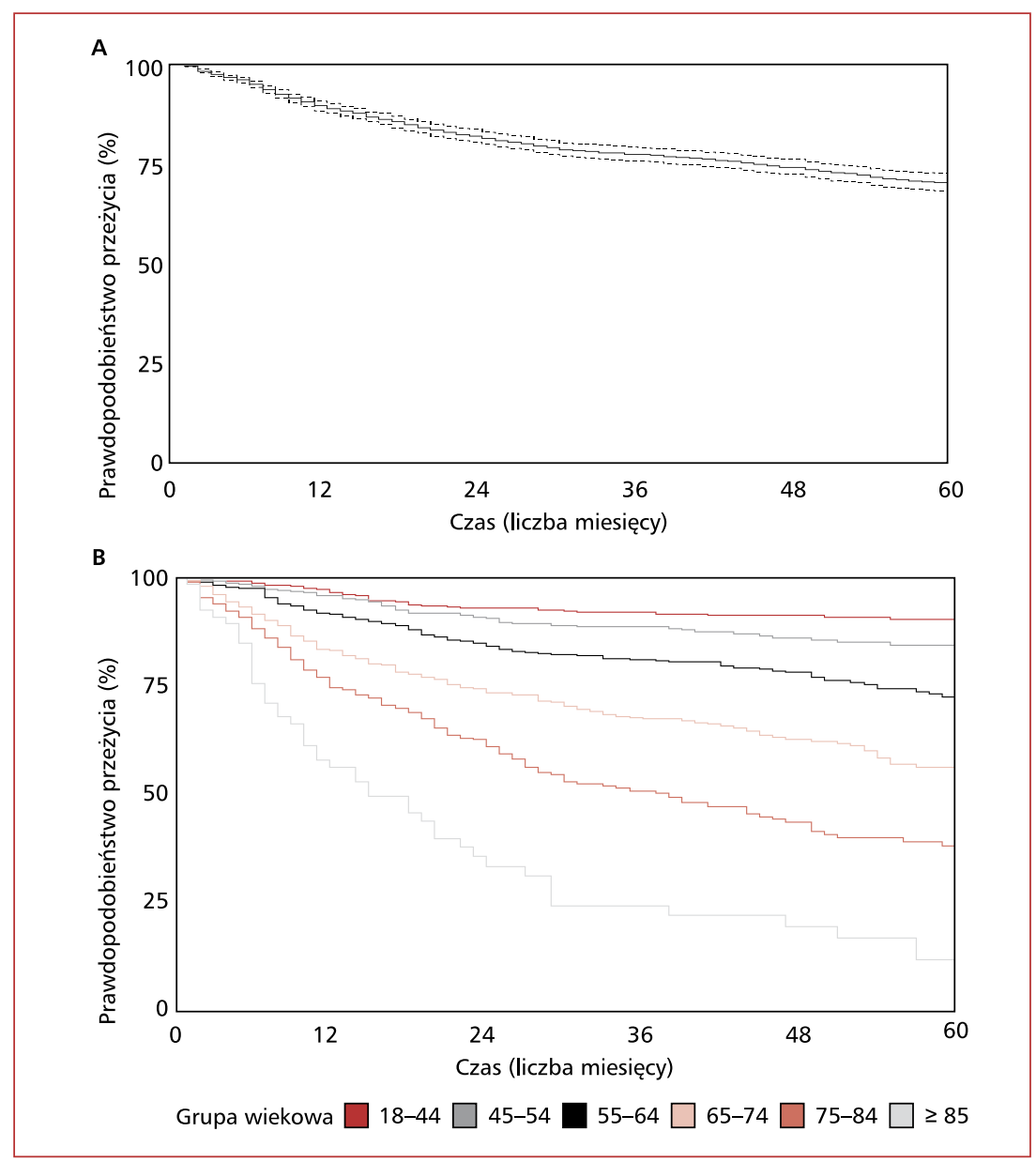

Rycina 11A, B. Prawdopodobieństwo przeżycia całkowitego chorych sprawozdawanych jako pacjenci z rozpoznaniem przewlekłej białaczki szpikowej (A) w zależności od grupy wiekowej (B)

Figure 11A, B. Probability of overall survival in patients registered as having chronic myelogenous leukemia (A) according to the age group (B)

rejestrowanych $\mathrm{z}$ użyciem kodów MPN $\mathrm{Ph}(-)$ prawdopodobieństwo 3- i 5-letniego OS oszacowano, odpowiednio, na $86,6 \%$ oraz $78,6 \%$ chorych. $Z$ kolei mediana OS u chorych raportowanych $z$ uzyciem kodu MDS wynosiła 30 miesięcy, prawdopodobieństwo 3-letniego OS osiągnęło 45,8\%, a 5-letniego
OS - 36,1\% chorych. Obliczono również prawdopodobieństwo OS w zależności od grupy wiekowej z przedstawieniem ich 5-letnich wartości u chorych na CML (ryc. 11B, tab. 5) i MPN Ph(-) (ryc. 12B, tab. 6) oraz 3- i 5-letnich wartości u chorych na MDS (ryc. 13B, tab. 7). 


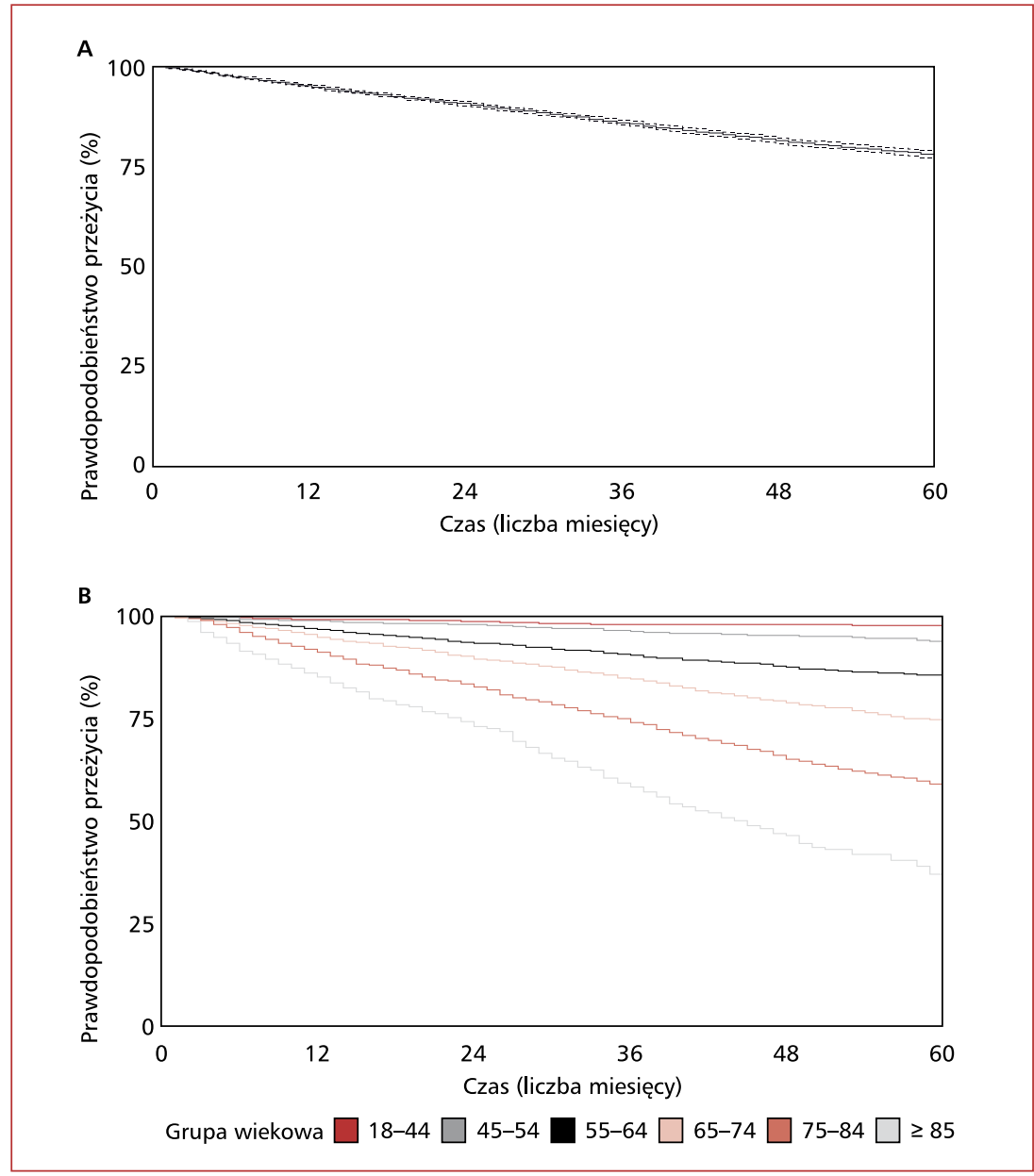

Rycina 12A, B. Prawdopodobieństwo całkowitego przeżycia chorych sprawozdawanych jako pacjenci z rozpoznaniami nowotworów mieloproliferacyjnych Filadelfia-ujemnych (A) w zależności od grupy wiekowej (B)

Figure 12A, B. Probability of overall survival in patients registered as having myeloproliferative neoplasms Philadelphia-negative (A) according to the age group (B)

Tabela 5. Szacowane 5-letnie przeżycia całkowite (OS) chorych sprawozdawanych jako pacjenci z rozpoznaniem przewlekłej białaczki szpikowej w zależności od grupy wiekowej

Table 5. Estimated 5-year overall survival (OS) in patients registered as having chronic myelogenous leukemia according to the age group

\begin{tabular}{|l|c|c|}
\hline $\begin{array}{l}\text { Grupa wiekowa } \\
\text { (lata) }\end{array}$ & $\begin{array}{c}\text { Mediana } \\
\text { (miesiące) }\end{array}$ & $\begin{array}{c}\text { 5-lenie OS } \\
\text { (zakres) }\end{array}$ \\
\hline $18-44$ & $>60$ & $\begin{array}{c}90 \% \\
(87-93 \%)\end{array}$ \\
\hline $45-54$ & $>60$ & $\begin{array}{c}83 \% \\
(79-88 \%)\end{array}$ \\
\hline $55-64$ & $>60$ & $\begin{array}{c}72 \% \\
(68-77 \%)\end{array}$ \\
\hline $65-74$ & $>60$ & $\begin{array}{c}55 \% \\
(49-61 \%)\end{array}$ \\
\hline $75-84$ & 35 & $\begin{array}{c}36 \% \\
(30-44 \%)\end{array}$ \\
\hline$\geq 85$ & 15 & $\begin{array}{c}10 \% \\
(4-30 \%)\end{array}$ \\
\hline
\end{tabular}

Tabela 6. Szacowane 5-letnie całkowite przeżycia (OS) chorych sprawozdawanych jako pacjenci z rozpoznaniami nowotworów mieloproliferacyjnych Filadelfia-ujemnych w zależności od grupy wiekowej

Table 6. Estimated 5-year overall survival (OS) in patients registered as having myeloproliferative neoplasms Philadelphia-negative according to the age group

\begin{tabular}{|l|c|c|}
\hline $\begin{array}{l}\text { Grupa wiekowa } \\
\text { (lata) }\end{array}$ & $\begin{array}{c}\text { Mediana } \\
\text { (miesiące) }\end{array}$ & $\begin{array}{c}\text { 5-lenie OS } \\
\text { (zakres) }\end{array}$ \\
\hline $18-44$ & $>60$ & $\begin{array}{c}98 \% \\
(97-98 \%)\end{array}$ \\
\hline $45-54$ & $>60$ & $\begin{array}{c}94 \% \\
(92-95 \%)\end{array}$ \\
\hline $55-64$ & $>60$ & $\begin{array}{c}86 \% \\
(84-87 \%)\end{array}$ \\
\hline $65-74$ & $>60$ & $\begin{array}{c}74 \% \\
(72-76 \%)\end{array}$ \\
\hline $75-84$ & 45 & $\begin{array}{c}58 \% \\
(56-60 \%)\end{array}$ \\
\hline$\geq 85$ & & $\begin{array}{c}36 \% \\
(30-43 \%)\end{array}$ \\
\hline
\end{tabular}




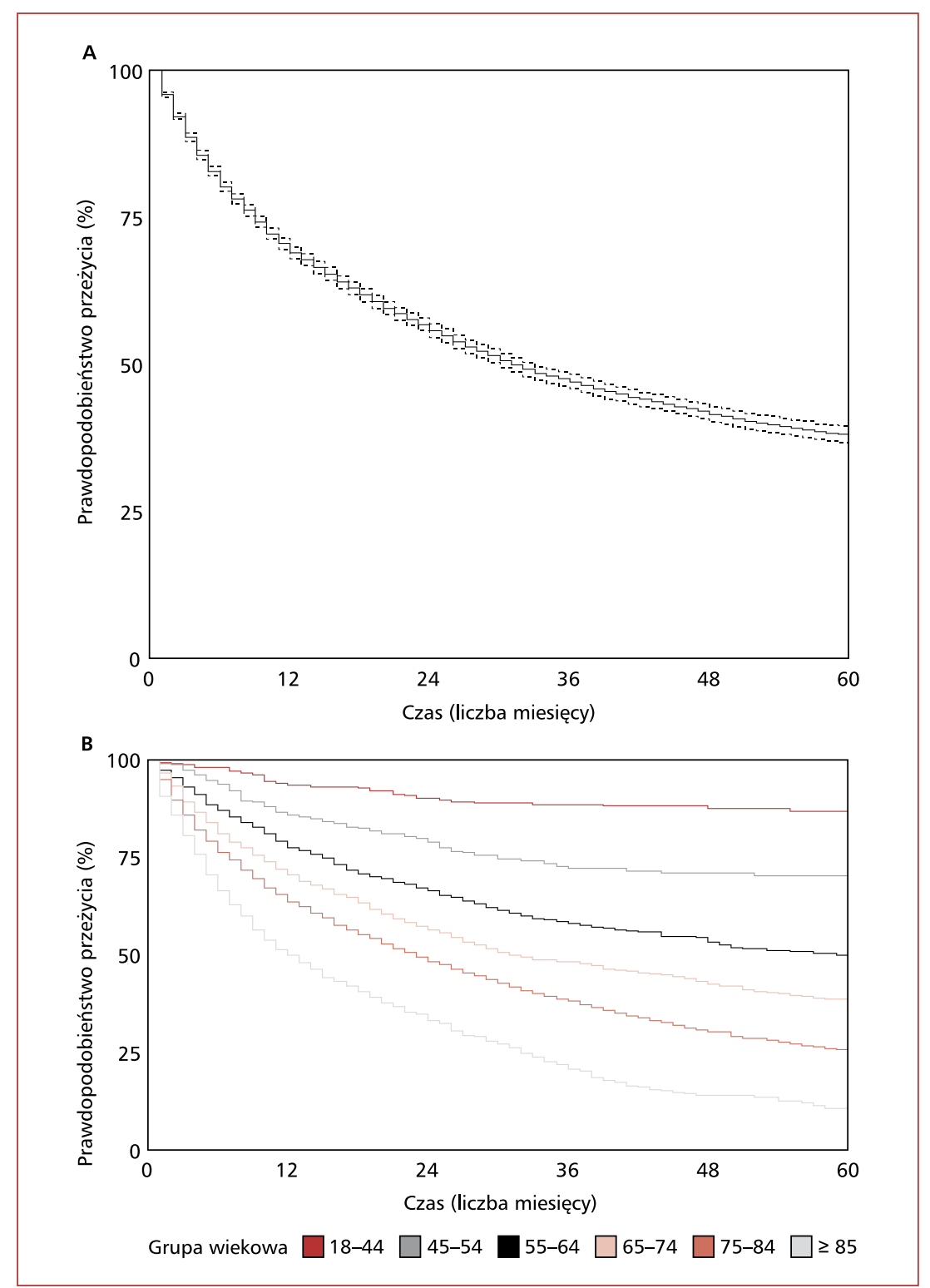

Rycina 13A, B. Prawdopodobieństwo przeżycia całkowitego (OS) chorych sprawozdawanych jako pacjenci z rozpoznaniem zespołu mielodysplastycznego (A) w zależności od grupy wiekowej (B)

Figure 13A, B. Probability of overall survival in patients registered as having myelodysplastic syndrome $(A)$ according to the age group (B)

\section{Dyskusja}

\section{Ostre białaczki szpikowe}

Według danych SEER (Surveillance, Epidemiology, and End Results Program) NCI (National Cancer Institute) liczba nowych zachorowań na AML w populacji amerykańskiej, na podstawie danych epidemiologicznych $z$ lat 2010-2014, wynosi 4,2 przypadku/100 tys./rok. Pozwala to oszacować liczbę nowych przypadków zachorowań w 2017 roku na 21380 [9]. $Z$ kolei analiza największego europejskiego badania HAEMACARE, w którym raportowano dane dotyczące częstości występo- wania chorób z 44 europejskich rejestrów chorób nowotworowych w latach 2000-2002, wykazała, że współczynnik zapadalności na AML w Europie wynosił 3,62 (8107 nowych przypadków) [10]. W 2015 roku opublikowano raport $\mathrm{z}$ utworzonego w 2003 roku w Instytucie Hematologii i Transfuzjologii (IHT) Rejestru Zachorowań na Ostre Białaczki u Osób Dorosłych [11]. Rejestr był oparty na zgłoszeniach przesyłanych $\mathrm{w}$ formie ankiet $\mathrm{z}$ ośrodków hematologicznych w Polsce współpracujących w ramach Polskiej Grupy ds. Leczenia Białaczek u Dorosłych (PALG, Polish Adult Leukemia Group). Na podstawie analizy zachorowań zgłoszonych od 
Tabela 7. Szacowane 3- i 5-letnie przeżycia całkowite (OS) chorych sprawozdawanych jako pacjenci z rozpoznaniem zespołu mielodysplastycznego w zależności od grupy wiekowej

Table 7. Estimated 3- and 5-year overall survival (OS) in patients registered as having myelodysplastic syndrome according to the age group

\begin{tabular}{|l|c|c|c|}
\hline $\begin{array}{l}\text { Grupa wiekowa } \\
\text { (lata) }\end{array}$ & $\begin{array}{c}\text { Mediana } \\
\text { (miesiące) }\end{array}$ & $\begin{array}{c}\text { 3-lenie OS } \\
\text { (zakres) }\end{array}$ & $\begin{array}{c}\text { 5-lenie OS } \\
\text { (zakres) }\end{array}$ \\
\hline $18-44$ & $>60$ & $\begin{array}{c}89 \% \\
(85-92 \%)\end{array}$ & $\begin{array}{c}87 \% \\
(83-91 \%)\end{array}$ \\
\hline $45-54$ & 57 & $\begin{array}{c}72 \% \\
(67-77 \%)\end{array}$ & $\begin{array}{c}78 \% \\
(65-75 \%)\end{array}$ \\
\hline $55-64$ & 31 & $\begin{array}{c}45 \%-61 \%) \\
(45-50 \%)\end{array}$ & $\begin{array}{c}49 \% \\
(46-53 \%)\end{array}$ \\
\hline $65-74$ & 22 & $\begin{array}{c}37 \% \\
(35-40 \%)\end{array}$ \\
\hline $75-84$ & 12 & $\begin{array}{c}20 \% \\
(17-23 \%)\end{array}$ & $\begin{array}{c}24 \% \\
(21-26 \%)\end{array}$ \\
\hline$\geq 85$ & $7-13 \%)$ \\
\hline
\end{tabular}

2004 do 2010 roku surowy współczynnik zachorowalności na AML wynosił średnio 2,17/100 tys.

Przedstawione w pracy dane dotyczące rejestrowanej zapadalności i chorobowości uzyskane na podstawie analizy świadczeń sprawozdawanych do NFZ należy więc uznać za zbliżone do danych amerykańskich $z$ lat 2010-2014. Z kolei przeszacowanie zapadalności na AML w Polsce w porównaniu $z$ danymi $z$ badania HAEMACARE może wynikać $z$ tego, $\dot{z}$ e raport HAEMACARE obejmowal przypadki zachorowania na AML w latach 2000-2002, a wiadomo, że w ostatnich kilkunastu latach obserwuje się wzrost zachorowalności na ostre nowotwory układu krwiotwórczego oraz poprawę zgłaszalności nowotworów do rejestrów.

Analiza zachorowań na AML w grupach wiekowych na podstawie danych NFZ dowiodła zwiększania się liczby zachorowań $z$ wiekiem. Podobny trend obserwowano w innych rejestrach, a także w Rejestrze Zachorowań na Ostre Białaczki u Dorosłych w Polsce, w którym największy współczynnik zachorowalności w odniesieniu do AML stwierdzono $\mathrm{w}$ grupie chorych $\mathrm{w}$ wieku $70 \mathrm{i}$ więcej lat $(4,59$ / /100 tys.) [11]. Otrzymana w wyniku badania mediana wieku chorych jest zbliżona do tych raportowanych w innych badaniach [1, 11-13]. W grupie chorych sprawozdawanych $z$ rozpoznaniem AML zaznacza się niewielka przewaga mężczyzn (53\%), podobnie jak w innych rejestrach $[2,11]$.

Prawdopodobieństwo OS chorych rejestrowanych w systemie NFZ z użyciem kodów AML było porównywalne $z$ raportowanymi w innych krajach. Według danych SEER, w latach 2007-2013, 5-letnie względne przeżycie osiągało $26,9 \%$ chorych [9]. Należy jednak podkreślić, że populacyjne wskaźniki określają przeżycie względne oszacowane jako wskaźnik przeżycia obserwowanego do przeżycia oczekiwanego u wszystkich osób w danym wieku i danej płci w badanej populacji, które może się różnić od przeżycia obserwowanego obliczanego metodą Kaplana-Meiera. W Wielkiej Brytanii prawdopodobieństwo 5-letniego OS wynosiło 26\% [14], w Australii - 24,5\% [13], a w Europie według badania HEMACARE - $17 \%$ [15]. Z kolei dane $z$ Rejestru Zachorowań na Ostre Białaczki u Dorosłych w Polsce wskazują, że w grupie chorych na AML mediana OS wynosiła również 6 miesięcy, a prawdopodobieństwo 3-letniego OS oszacowano metodą Kaplana-Meiera - 18,9\% (7,6 pkt. procentowego niższe od otrzymanego w badaniu), zaś 5-letniego OS - 16\% (7,4 pkt. procentowego niższe od otrzymanego w badaniu) [11]. Niższe wskaźniki przeżyć obserwowanych, które raportowano w tym Rejestrze, w porównaniu ze wskaźnikami $z$ prezentowanego $\mathrm{w}$ niniejszej pracy badania, mogą wynikać $z$ faktu, że Rejestr opierał się na dobrowolnym raportowaniu danych przez poszczególne ośrodki hematologiczne i nie odzwierciedlał rzeczywistej liczby chorych na AML w Polsce [11]. Czas przeżycia chorych z Rejestru był znamiennie dłuższy w grupie osób młodszych - poniżej 60. roku życia (mediana OS 13,2 miesiąca; prawdopodobieństwo 3-letniego OS - 31,4\%) — niż wśród osób starszych (mediana OS 3,6 miesiąca, prawdopodobieństwo 3-letniego OS $-6,5 \%)$. W innych rejestrach również wykazano, że $z$ wiekiem znamiennie skraca się OS chorych na AML $[16,17]$.

\section{Nowotwory mieloproliferacyjne}

Według danych HAEMACARE współczynnik zapadalności na MPN wyniósł 3,34 (7474 nowych przypadków), w tym na CML $-1,10$ oraz na pozostałe MPN $-2,24$, natomiast na wszystkie rodzaje MDS - 1,82 (4074 nowych przypadków) i nowotwory MDS/MPN reprezentowane głównie przez przewlekłą białaczkę mielomonocytową (CMML, chronic myelomonocytic leukemia) - 0,35 (756 nowych przypadków). Niestety, w wyżej wymienionym rejestrze dane polskie pochodziły tylko $z 3$ ośrodków, tj. z Krakowa, Kielc i Warszawy, które łącznie obejmowały jedynie 9,2\% populacji kraju [10].

Moulard i wsp. [18] przeanalizowali rejestry chorób nowotworowych obejmujące lata 2000-2012 i zaobserwowali, że zapadalności na MPN na 
świecie wahają się od 0,44 do 5,87/100 tys. ludności, przy czym najniższa zapadalność była raportowana w Japonii i Izraelu. W krajach Unii Europejskiej zapadalność na PMF mieściła się w zakresie od 0,1 do 1,0/100 tys. osób/rok, a na PV — od 0,4 do 2,8/100 tys./rok, co odpowiada łącznej zapalności szacowanej określonej w literaturze na 0,68 do 2,6/100 tys./rok. Szacowana zapadalność na ET pozostawała w zakresie od 0,38 do $1,7 / 100$ tys./ /rok [18]. Z kolei w największym populacyjnym badaniu służącym ocenie zachorowalności i prawdopodobieństwa OS chorych na MPN i MDS/MPN w Stanach Zjednoczonych w latach 2001-2012 prowadzonym na podstawie danych SEER obserwowano, że zapadalność na wszystkie MPN, w tym MDS/MPN, wyniosła 32,4/ $1 \mathrm{mln}$, przy czym współczynnik zapadalności na PV oszacowano na 10,9/1 mln, ET na 9,6/1 mln, MF na 3,1/1 mln, a współczynnik zapadalności na CML wyniósł 3,3/ $/ 1$ mln [19]. Rollison i wsp. [20] analizowali zapadalność na MPN w latach 2001-2003 na podstawie rejestrów NAACCR (North American Association of Central Cancer Registries) i SEER. Według ich danych zapadalność na MDS była wyższa niż na MPN i wynosiła, odpowiednio, 3,3 i 2,1/100 tys. ludności [20]. Zarówno w badaniach europejskich, jak i amerykańskich obserwuje się częstsze występowanie MPN u mężczyzn niż u kobiet, i to niezależnie od wieku. Wyjątek stanowi ET, w której zapadalność jest większa wśród kobiet, zwłaszcza poniżej 60. roku życia [10, 18-21]. Wskaźnik chorobowości, według danych amerykańskich dotyczących lat 2008-2010, w przypadku PV wynosił 44-57/ /100 tys., w przypadku ET $-38-57 / 100$ tys., natomiast $\mathrm{w}$ odniesieniu do PMF $-4-6 / 100$ tys. [22].

Prezentowane dane dotyczące rejestrowanej zapadalności i chorobowości na MPN uzyskane na podstawie analizy świadczeń sprawozdawanych do NFZ różnią się od danych pochodzących $z$ piśmiennictwa i te pierwsze należy uznać za górne granice przedziałów w odniesieniu do zapadalności, a dolne granice przedziałów - w odniesieniu do chorobowości, co wskazywałoby na to, że up-coding dotyczy chorób, w przebiegu których przeżywalność jest niska. Obserwowane różnice między danymi sprawozdawanymi do NFZ a danymi $z$ badania HAEMACARE czy amerykańskimi mogą być również spowodowane takimi przyczynami, jak niedostateczna jakość raportowanych danych czy niedostosowanie kodów ICD-10 do obecnie obowiązującej klasyfikacji MPN według WHO. Dlatego konieczne jest wprowadzenie do sprawozdawczości najbardziej aktualnych wersji $(2015,2016)$ klasyfikacji ICD-10 i monitorowanie jakości raportowanych danych. Ponadto należy wziąć pod uwagę możliwość sprawozdawania zarówno wtórnej czerwienicy, jak i wtórnej nadpłytkowości jako zaburzeń pierwotnych. Wreszcie istnieje możliwość sprawozdawania niektórych przypadków PMF w fazie proliferacyjnej jako ET.

\section{Zespoły mielodysplastyczne}

Dane $z$ piśmiennictwa dotyczące wskaźników zapadalności, chorobowości i przeżycia w MDS pochodzą przede wszystkim $z$ rejestrów amerykańskich, badania HAEMACARE [10] i opublikowanej w 2016 roku analizy brytyjskiej bazy Haematological Malignancy Research Network [23].W badaniu HAEMACARE surowy współczynnik zapadalności na MDS w latach 2000-2002 wyniósł 1,82/100 tys./ /rok, odpowiednio 2,03 u mężczyzn i 1,62 u kobiet [10]. Analiza Roman i wsp. [23] dotyczyła $4 \mathrm{mln}$ pacjentów znajdujących się w brytyjskiej bazie $H a$ ematological Malignancy Research Network zdiagnozowanych w latach 2004-2013 i obserwowanych do 1 sierpnia 2015 roku. Surowy współczynnik zapadalności na wszystkie rodzaje MDS wyniósł 3,72 (1194 nowych przypadków), a standaryzowany pod względem wieku - 4,44 (odpowiednio, u mężczyzn 5,1 i 7,41 oraz u kobiet 2,41 i 2,53 ). Chorobowość w ciagu 3 lat wyniosła 6,3/100 tys. osób i wzrosła do 10,9 w ciągu 10 lat. Prawdopodobieństwo 5 -letniego OS osiągnęło $21,1 \%$ — odpowiednio 19,2\% mężczyzn i 24,8\% kobiet — i różniło się znacznie w zależności od podtypu choroby. U pacjentów $z$ MDS 5q- wynosiło 53,7\%, natomiast $\mathrm{u}$ chorych na MDS $\mathrm{z}$ niedokrwistością oporną na leczenie $z$ nadmiarem blastów (RAEB, refractory anemia with excess of blasts) - 7,9\%. Autorzy obserwowali wyższą zapadalność na MDS i krótsze OS u mężczyzn [23].

$Z$ kolei Rollison i wsp. [20] w 2004 roku obserwowali nieznaczny, ale statystycznie istotny wzrost zapadalności na MDS do 3,8/100 tys., co tłumaczono zwiększeniem liczby raportowanych przypadków. Jednocześnie autorzy uważają, że zapadalność na MDS wydaje się mocna niedoszacowana, co może być związane między innymi z niską rozpoznawalnością MDS, szczególnie u starszych chorych pozostających pod opieką lekarzy podstawowej opieki $z$ powodu niedokrwistości i niekierowanych na dalszą diagnostykę. W swojej pracy Rollison i wsp. porównali również współczynnik zapadalności na MDS w Stanach Zjednoczonych w latach 2001-2003 do wskaźników w 15 krajach europejskich, stwierdzając, że są one zbliżone. Dla przykładu w Anglii i Walii zapadalność wynosiła 3,6/100 tys. [24], w Niemczech $-4,1 / 100$ tys. 
[25], w Szwecji - 3,6/100 tys. [26], we Francji $3,2 / 100$ tys. [27]. W analizowanym okresie 3-letnie OS osiagnęło 45\% chorych na MDS [14]. Zaobserwowano, że czynniki ryzyka zachorowania na MPN i MDS to starszy wiek, płeć męska i biała rasa [20].

Według Rejestru PALG [28] surowy wspó1czynnik zapadalności w odniesieniu do wszystkich podtypów MDS wynosi 1,95/100 tys./rok; 2,46 u mężczyzn i 1,47 u kobiet. Po wykluczeniu AML wskaźniki te wynosiły, odpowiednio, 2,35 (95-proc. przedział ufności [CI, confidence interval] 2,08-2,66) u mężczyzn i 1,27 (95\% CI 1,08-1,5) u kobiet. Wskaźnik chorobowości wynosił 6,2/100 tys. osób (95\% CI 5,96-6,45); 6,86 (95\% CI 6,49-7,24) u mężczyzn i 5,58 (95\% CI 5,26-5,92) u kobiet. Zarówno zapadalność, jak i chorobowość zwiększały się $z$ wiekiem. Najczęściej diagnozowanym podtypem MDS była oporna na leczenie cytopenia $z$ wieloliniową dysplazją (RCMD, refractory cytopenia with multilineage dysplasia) i stanowiła ona $30,3 \%$ wszystkich nowo zdiagnozowaych przypadków MDS [28].

Zarówno wskaźnik zapadalności, jak i chorobowości pacjentów sprawozdawanych do NFZ z użyciem kodu D46 są porównywalne ze wskaźnikami w rejestrach amerykańskich i brytyjskim. Różnice w porównaniu $z$ badaniem HAEMACARE wynikają najprawdopodobniej $z$ okresu, w jakim to badanie prowadzono (lata 2000-2002). Porównując wskaźniki zapadalności i chorobowości na MDS, należy wziąć pod uwagę dużą heterogenność tych zespołów i wysoką, w porównaniu $z$ nowotworami litymi, skłonność do transformacji. Niektóre podtypy MDS, takie jak MDS RAEB, już w samej swojej biologii predysponują do rozwoju AML. $Z$ tego powodu mogą występować różnice w rejestrowaniu chorych. Odrębnym zagadnieniem są trudności diagnostyczne w rozpoznawaniu MDS i różnicowaniu $z$ mielodysplazją, co może niekiedy wynikać $z$ niezgodności między laboratoriami $\mathrm{w}$ ocenie morfologii szpiku u chorych na MDS $[20,23]$. Należy również uwzględnić okresy, $z$ jakich rejestry pochodzą. Widać wyraźną tendencję do wzrostu wskaźników zapadalności i chorobowości w ostatniej dekadzie. Jest to najprawdopodobniej związane $z$ poprawą systemów rejestracyjnych i większą zgłaszalnością przypadków MDS. Wyższy wskaźnik 5-letniego OS u chorych raportowanych do NFZ $(36,1 \%)$ w porównaniu $z$ danymi brytyjskimi $(21,1 \%)$ może wynikać $\mathrm{z}$ faktu, że brytyjski raport opierał się na danych populacyjnych i prezentował przeżycia względne [23]. W interpretacji tych wyników należy wziąć także pod uwagę naturalną transformację MDS do AML i możliwość sprawozdawania pacjentów w przypadku dłuższego okresu ich obserwacji z użyciem kodu C92.0, a nie kodu D46, jak w przypadku MDS.

\section{Podsumowanie}

W Polsce, poza KRN, którego niewystarczającą jakość danych dotyczących nowotworów układu krwiotwórczego omówiono we wprowadzeniu, Rejestrem Zachorowań na Ostre Białaczki u Dorosłych oraz rejestrem MDS prowadzonymi przez PALG i opartymi na dobrowolnej zgłaszalności nowych zachorowań na nowotwory przez badaczy, nie ma danych epidemiologicznych dotyczących nowotworów układu krwiotwórczego. Dlatego też prezentowane w niniejszej pracy wskaźniki, które opierają się na danych sprawozdawanych do NFZ w celu uzyskania refundacji świadczeń, wydają się najbardziej rzetelnymi danymi obejmującymi tak dużą populację chorych na nowotwory układu krwiotwórczego. Co więcej, są to pierwsze dane określające chorobowość na te nowotwory. $Z$ jednej strony, biorąc pod uwagę fakt, że dane sprawozdawane do NFZ mogą być obarczone błędem wynikającym $z$ niedostatecznej jakości systemu kodowania chorób nowotworowych oraz niedostosowaniem X Rewizji ICD-10 do obowiązujących klasyfikacji WHO, są one zbliżone do danych $z$ rejestrów europejskich i amerykańskich w odniesieniu do AML i MDS, a w zakresie MPN ( $z$ wyjątkiem CML) - wymagają dalszej weryfikacji. $Z$ drugiej strony, niewątpliwie, oddają one rzeczywiste obciążenie polskiego systemu ochrony zdrowia chorobami nowotworowymi układu krwiotwórczego i to stanowi ich najważniejszą wartość.

\section{Piśmiennictwo}

1. Więckowska B, Koń B, Dagiel J. et al. Choroby onkologiczne w Polsce - wyniki modelu prognostycznego na lata 2015-2025. In: Więckowska B. ed. Onkologia. Vol. 1. Proces leczenia w Polsce — analizy i modele. Ministerstwo Zdrowia, Warszawa 2015: 292.

2. http://www.mapypotrzebzdrowotnych.mz.gov.pl/mapy-dla-30-grup-chorob/ (30.06.2017).

3. R Core Team. R: a language and environment for statistical computing. R Foundation for Statistical Computing, Vienna, Austria, 2016. https://www.R-project.org/ (30.06.2017).

4. RStudio Team. RStudio: Integrated Development for R. RStudio. Inc., Boston 2015. http://www.rstudio.com/.

5. Dowle M, Srinivasan A. data.table: Extension of 'data.frame'. $\mathrm{R}$ package version 1.10.4, 2017. https:/CRAN.R-project.org/ /package $=$ data.table.

6. Wickham H. ggplot2: elegant graphics for data analysis. Springer-Verlag, New York 2016. http://ggplot2.org (30.06.2017).

7. Therneau T. A package for survival analysis in S. version 2.38. 2015. http://CRAN.R-project.org/package = survival (30.06.2017). 
8. Therneau T, Grambsch PM. Modeling survival data: extending the Cox model. Springer, New York 2000.

9. https://seer.cancer.gov/ (30.06.2017).

10. Sant M, Allemani C, Tereanu C, et al. HAEMACARE Working Group. Incidence of hematologic malignancies in Europe by morphologic subtype: results of the HAEMACARE project. Blood. 2010; 116(19): 3724-3734, doi: 10.1182/blood-2010-05-282632, indexed in Pubmed: 20664057.

11. Seferyńska I, Warzocha K. Raport $\mathrm{z}$ rejestru zachorowań na ostre białaczki u osób dorosłych w Polsce w latach 2004-2010 prowadzonego przez Instytut Hematologii i Transfuzjologii w imieniu Polskiej Grupy ds. Leczenia Białaczek u Dorosłych (PALG). Hematologia. 2014; 5: 162-172.

12. Juliusson G, Lazarevic V, Hörstedt AS, et al. Swedish Acute Leukemia Registry Group. Acute myeloid leukemia in the real world: why population-based registries are needed. Blood. 2012; 119(17): 3890-3899, doi: 10.1182/blood-2011-12-379008, indexed in Pubmed: 22383796.

13. Gangatharan SA, Grove CS, P'ng S, et al. Acute myeloid leukaemia in Western Australia 1991-2005: a retrospective populationbased study of 898 patients regarding epidemiology, cytogenetics, treatment and outcome. Intern Med J. 2013; 43(8): 903-911, doi: 10.1111/imj.12169, indexed in Pubmed: 23611681.

14. Bhayat F, Das-Gupta E, Smith C, et al. The incidence of and mortality from leukaemias in the UK: a general population-based study. BMC Cancer. 2009; 9: 252, doi: 10.1186/1471-2407-9-252, indexed in Pubmed: 19630999.

15. Maynadié M, De Angelis R, Marcos-Gragera R, et al. HAEMACARE Working Group. Survival of European patients diagnosed with myeloid malignancies: a HAEMACARE study. Haematologica. 2013; 98(2): 230-238, doi: 10.3324/haematol.2012.064014, indexed in Pubmed: 22983589.

16. Thein MS, Ershler W, Jemal A, et al. Outcome of older patients with acute myeloid leukemia. Cancer. 2013; 119(15): 2720-2727, doi: 10.1002/cncr.28129.

17. Medeiros BC, Satram-Hoang S, Hurst D, et al. Big data analysis of treatment patterns and outcomes among elderly acute myeloid leukemia patients in the United States. Ann Hematol. 2015; 94(7): 1127 -1138, doi: 10.1007/s00277-015-2351-x, indexed in Pubmed: 25791241.

18. Moulard O, Mehta J, Fryzek J, et al. Epidemiology of myelofibrosis, essential thrombocythemia, and polycythemia vera in the European Union. Eur J Haematol. 2014; 92(4): 289-297, doi: 10.1111/ejh.12256, indexed in Pubmed: 24372927.
19. Srour SA, Devesa SS, Morton LM, et al. Incidence and patient survival of myeloproliferative neoplasms and myelodysplastic/ /myeloproliferative neoplasms in the United States, 2001-12. Br J Haematol. 2016; 174(3): 382-396, doi: 10.1111/bjh.14061, indexed in Pubmed: 27061824.

20. Rollison DE, Howlader N, Smith MT, et al. Epidemiology of myelodysplastic syndromes and chronic myeloproliferative disorders in the United States, 2001-2004, using data from the NAACCR and SEER programs. Blood. 2008; 112(1): 45-52, doi: 10.1182/ /blood-2008-01-134858, indexed in Pubmed: 18443215.

21. Titmarsh GJ, Duncombe AS, McMullin MF, et al. How common are myeloproliferative neoplasms? A systematic review and meta-analysis. Am J Hematol. 2014; 89(6): 581-587, indexed in Pubmed: 24971434.

22. Mehta J, Wang H, Iqbal SU, et al. Epidemiology of myeloproliferative neoplasms in the United States. Leuk Lymphoma. 2014; 55(3): 595-600, doi: 10.3109/10428194.2013.813500, indexed in Pubmed: 23768070.

23. Roman E, Smith A, Appleton S, et al. Myeloid malignancies in the real-world: occurrence, progression and survival in the UK's population-based Haematological Malignancy Research Network 2004-15. Cancer Epidemiol. 2016; 42: 186-198, doi: 10.1016/j. canep.2016.03.011, indexed in Pubmed: 27090942.

24. Cartwright R, Ricketts T. Leukaemias and lymphoma: an atlas of distribution within areas of England and Wales 1984-88. Leukaemia Research Fundation, London 1990.

25. Aul C, Gattermann N, Schneider W, et al. [Myelodysplastic syndromes. The epidemiological and etiological aspects]. Dtsch Med Wochenschr. 1992; 117(33): 1223-1231, doi: 10.1055/s-2008-1062434, indexed in Pubmed: 1499520.

26. Rådlund A, Thiede T, Hansen S, et al. Incidence of myelodysplastic syndromes in a Swedish population. Eur J Haematol. 1995; 54(3): 153-156, indexed in Pubmed: 7720834.

27. Maynadié M, Verret C, Moskovtchenko P, et al. Epidemiological characteristics of myelodysplastic syndrome in a well-defined French population. Br J Cancer. 1996; 74(2): 288-290, indexed in Pubmed: 8688338.

28. Drozd-Sokołowska JE, Mądry K, Waszczuk-Gajda A, et al. Are myelodysplastic syndromes underdiagnosed in Poland? A report by the Polish Adult Leukaemia Group. Eur J Haematol. 2017; 98(2): 154-159, doi: 10.1111/ejh.12814, indexed in Pubmed: 27699872 . 